\title{
Alcohol: Friend or Foe?
}

\section{Ricardo A. González MD PhD DrSc}

\begin{abstract}
Popular belief has it that alcohol, particularly red wine, protects against atherosclerosis and associated cardio- and cerebrovascular conditions. That presumption motivates this paper, which describes the mechanisms underlying the J-shaped risk curve for alcohol use, with benefits for vascular disease risk at low consumption levels and harmful effects-both directly on the user and indirectly on the bystander-at higher levels. The importance of further exploring alcohol use in patients with cardiovascular risk factors and of intervening to modify non-social use of alcohol to prevent serious adverse health consequences is also addressed.
\end{abstract}

KEYWORDS Alcohol-related disorders, burden of illness, atherosclerosis, atherogenesis, vascular disease, risk factors, Cuba

They tell me you dropped out of school and are drinking in alleyways. Beer will be your damnation. You are like a godless temple or a house without bread.

-Your father

This short and anguished message was inscribed on a clay tablet five thousand years ago,[1] the first written evidence of people who drank to excess and others who were deeply affected by it. In today's world, cardiovascular diseases and cancers are the main causes of sickness and death, and their principal risk factors are tobacco addiction and non-social use of alcohol.[2] Although at a global level tobacco is the main culprit of this grim picture, non-social use of alcohol is associated with no fewer than 60 diseases.[3,4] And in the Americas, alcohol is the main diseaseproducing risk factor among 27 countries monitored by $\mathrm{PAHO}$. Thus, I would argue that it is imperative to establish a common hemisphere-wide conditional tolerance of alcohol, leaving behind the habitual unconditional tolerance that has made both alcohol use and drunkenness socially acceptable in the region.

Cuba's epidemiologic picture, including the role of tobacco and alcohol as cardiovascular and cancer risk factors, is similar to the rest of the Americas. Hence, the need for deeper reflection on aspects such as the difference between alcohol's effects at low doses and those at doses exceeding WHO-established thresholds for its health benefits. In a previous article, I emphasized the importance of using both quantitative and qualitative criteria to define harmful, non-social alcohol use.[7]

It is well recognized that true social drinking-especially of red wine-is not harmful to the user and that it is even healthy when limited to half a glass every other day, as it reduces risk of multiple vascular conditions stemming from atherosclerosis. The science is equally strong that non-social use of alcohol is an atherogenic risk factor of the first order, multiplying the risk of myocardial infarction and ischemic stroke; $[8,9]$ and risk is even higher when smoking is added to the equation.[10]

\section{BENEFITS}

Alcohol's preventive potential was inferred from the so-called "French paradox" described in 1992, when low rates of athero- sclerotic heart disease were observed in France, despite high animal fat content in the French diet.[11] This was attributed to the antioxidant effects of red wine's high content of polyphenols such as resveratrol.[12] Alcohol and polyphenols reduce oxidative stress and increase LDL efflux from vascular walls by increasing HDL; they also inhibit lipoprotein oxidation, cholesterol accumulation in macrophages and formation of foam cells (LDL-containing phagocytes). They increase the bioavailability of nitric oxidewhich inhibits endothelial dysfunction-reduce blood viscosity, increase insulin sensitivity, and reduce platelet hyperactivity and fibrinogen-potentiated adhesion to vascular endothelium.[13]

Lorenzo et al. highlight the vasodilating effect of acetate, produced by catabolism of alcohol, adding the protective effect of dilation of the vasa vasorum to the protection of the vascular wall. They also describe moderate anti-inflammatory and other effects derived from increases in estrogen levels. As do other authors, they point out biochemical effects plus those on plasma coagulation factors, together with reduced insulin resistance and fibrinogenesis, as well as induction of fibrinolysis in endothelial cells.[14]

In sum, the benefits of doses as small as a half a glass of wine every other day are derived from action on cell signalling, gene expression, atherogenesis, oxidative processes, bioavailability of nitric oxide, vessel caliber, coagulation, fibrinolyis, estrogen levels and lowered blood pressure, the ultimate result being reduced cardiovascular risk and increased longevity.[14]

Although the greatest protective effects are reported for red wine, small doses of other types of alcohol also have benefits, albeit more modest because they lack the antioxidant effect that appears to be the chief feature of red wine, and because they tend to be higher in calories, potentially contributing to obesity.[13]

\section{HARMS}

In contrast, non-social use of alcohol-including drinking to get drunk and binge drinking-results, through an inversion of the mechanisms described above, in the tragic induction of an atherogenic process that multiplies by a factor of six the risk of cardiac, cerebral and peripheral vascular disease.[15] Added to these are myocardiotoxic and arrhythmogenic effects, immune suppression, systemic oxidants, increased vitamin demand with consequent negative impact on nutrition, and imbalance between nicotine adenine dinucleotide hydroxylase and nicotine adenine dinucleotide, and disruption of normal lipid metabolism.[16]

Alcohol also contributes to increased LDL through acetate from alcohol catabolism; and directly affects the adrenal cortex, stimulating production of glucocorticoids and mineralocorticoids and hence raising blood pressure.[16] The direct effect of ethanol on the vascular wall's smooth muscle is to increase its calcium ion content, narrowing the coronary, cerebral, renal peripheral and retinal arteries.[14]

The ultimate impact is premature development of atherosclerosis in the heart, brain, kidney and peripheral vascular system, even 
without the sinister effects of smoking, which increase the damage, creating a systemic catastrophe.[10]

At one time, the hypertensive effect was believed due to increased circulating blood volume related to beer consumption, leading to recommendations to substitute higher-proof beverages for beer. We now know that the mechanism is adrenocortical, as described earlier, although excessive beer intake does increase abdominal fat accumulation, in itself an important risk factor for cardiovascular diseases and part of the metabolic syndrome.[14]

Histochemically, initial cell membrane permeability becomes functional rigidity when part of the arachidonic acid in membrane phospholipids is progressively replaced by oleic and eicosatrienoic molecules, reducing protein content and myofibrillary contractility. This is a pathogenic factor in dilated cardiomyopathies, which tend to be much more severe in women.[12]

Changes associated with electrolyte disturbances are also responsible for cardiac arrhythmias such as extrasystoles, paroxysmal auricular tachycardia, auricular flutter and prolonged QT segment, as well as fatal events such as "holiday heart" (found relatively frequently in persons with low alcohol tolerance who drink excessively at a party and suffer serious arrhythmias that may lead to death from ventricular fibrillation).[17] Added to these toxic effects are those of other constituents of alcoholic beverages, such as methanol, furfural, fusel oils, acetaldehyde, formate and ethyl acetate.

Thus, we observe the epidemiologic phenomenon of the $\mathrm{J}$ shaped curve: that is, alcohol's effect on cardiovascular risk is not a straight line rising with dose, but at lower doses has a relative risk of $<1$, becoming $>1$ and increasing in a dose-dependent fashion once consumption exceeds social use levels.[12]

In assessing overall burden of alcohol-related disease and death-including potential years of life lost and disabilityadjusted years of life-we too often overlook the somatic repercussions on families, friends and co-workers that are independent of actual injury due to family violence.[8] Just as smoking affects bystanders' health through secondhand smoke, so does use of alcohol and other drugs affect those close to the user, but the vector is brutal stress that frequently leaves its mark through the psychoneuroimmunological axis, producing numerous conditions including hypertension, hyperlipidemia, obesity, immunosuppression and more.[18]

\section{CONCLUSIONS}

Non-social alcohol use is a major cause of atherosclerosis and its resulting cardiovascular, cerebrovascular, renal, retinal and peripheral vascular consequences. It is therefore advisable to assess alcohol intake and offer preventive counseling to patients with any of the above diseases or their risk factors, and to anyone presenting with depression, anxiety of unknown origin or early vascular dementia.

Finally, despite the demonstrated benefits of alcohol at low doses, considering the sociocultural tendency to excessive drinking in the Americas and applying the risk-benefit principle, abstainers should never be advised to start drinking for preventive purposes, especially in places such as Cuba where red wine consumption is rare. The potential harm from non-social use is just too great. -1 .

\section{REFERENCES}

1. Escohotado A. Historia General de las Drogas. Madrid: Editorial Espasa Calpe; 1998 Mar. 1542 p. Spanish.

2. Roses Periago M. La Salud Mental: Una prioridad de salud pública en las Américas. Rev Panam Salud Pública. 2005;18(4-5):223-5. Spanish.

3. Rehm J, Monteiro M. Alcohol consumption and burden of disease in the Americas implications for alcohol policy. Rev Panam Salud Pública. 2005 Oct-Nov; 18(4-5):241-8.

4. United Nations Office on Drugs and Crime (UNODC). [The World Drug Report]. Vienna: ONODC; 2008. Spanish.

5. Seuc $A H$, Domínguez Alonso E, Torres Vidal RM, Varona Pérez P. Algunas precisiones acerca de la mortalidad por enfermedades cardiovasculares en Cuba [Internet]. Rev Cub Salud Pública. 2011 Jan-Mar [cited 2011 Feb 10]; 37(1):19-33. Available from: http://www. bvs.sld.cu/revistas/spu/vol37_01_11/spu04111. htm. Spanish.

6. Armas NB, Ortega Y, Noval R, Suárez R, Llerena L, Dueñas A. Letalidad por infarto agudo del miocardio en Cuba 1999-2008. Rev Cub Cardiol Cir Cardiovasc [Internet]. 2011 Feb 14 [cited 2011 Aug 25];17(1):4-10. Available from: http://bvs.sld. cu/revistas/car/vol17_1_11/car02111.pdf. Spanish.

7. González R. Alcohol harm: beyond the body to the body politic. MEDICC Review. 2010 Oct;12(4):30-3.
8. Monteiro Mariestela G. Alcohol y Salud Pública en las Américas, un caso para la acción. Washington DC: OPS; 2007. Spanish.

9. Zhou X, Li C, Xu W, Hong X, Chen J. Relation of alcohol consumption to angiographically proved coronary artery disease in Chinese men. Am J Cardiol. 2010 Oct 15;106(8):1101-3.

10. Wakabayashi I. Associations between alcohol drinking and multiple risk factors for atherosclerosis in smokers and non-smokers. Angiology. 2010 Jul;61(5):495-503.

11. Renaud S, Lorgeril M. Wine, alcohol, platelets, and the French paradox for coronary heart disease. Lancet. 1992 Jun 20;339(8808):15236.

12. Lippi G, Franchini M, Favaloro EJ, Targher G. Moderate red wine consumption and cardiovascular disease risk: beyond the French paradox. Semin Thromb Hemost. 2010 Feb;36(1):59-70.

13. Chetreanu L, Liliescu ML. About wine intake and cardiovascular diseases. Rev Med Chir Soc Med Nat lasi. 2009 Jul-Sep 113(3):845-8. Romanian.

14. Lorenzo Fernández $\mathrm{P}$, Ladero JM, Leza JC Lizasoain I, editors. Drogodependencias. Farmacología. Patología. Psicología. Legislación. Madrid: Editorial Médica Panamericana; 1999. Spanish.

15. Rantakömi SH, Laukkanen JA, Kurl S Kauhanen J. Binge drinking and the progression of atherosclerosis in middle-aged men: an 11-year follow-up. Atherosclerosis. 2009 Jul;205(1):266-71.

16. Ciraulo G, Renner J, editors. Alcoholism, in Clinical Manual of Chemical Dependence. Washington DC: American Psychiatric Press; 1991. $420 \mathrm{p}$

17. Ettinger PO, Wu CF, De La Cruz C Jr, Weisse $A B$, Ahmed SS, Regan TJ. Arrhythmias and the "Holiday Heart": alcohol-associated cardiac rhythm disorders. Am Heart J. 1978 May;95(5):555-62.

18. Arce S. Inmunología Clínica y Estrés. Havana: Editorial Ciencias Médicas; 2007. 132 p. Spanish.

\section{AUTHOR}

Ricardo A. González Menéndez (isaric@ infomed.sld.cu), psychiatrist. Consulting professor at the Enrique Cabrera Medical Faculty of the Medical University of Havana.

Submitted: December 24, 2010

Approved for publication: October 1, 2011

Disclosures: None 